\title{
EFFECT OF ARTIFICIAL AGING TIME AND TEMPERATURE ON TENSILE STRENGTH OF DUPLEX STAINLESS STEELS SAF 2205 AND SAF 2304 USING (ABI) TECHNIQUE.
}

\author{
Ramadhan H. Gardi* \\ *University of Salahaddin / College of Engineering/ \\ Mechanical Department / Erbil / Iraq \\ E-mail: ramadhanhg@yahoo.com
}

\begin{abstract}
Two types of duplex stainless steels SAF 2205 and SAF 2305 have been selected in this study to investigate the effect of aging time and temperature on the tensile strength using (ABI) technique. Metallographic studies were conducted on heat treated duplex stainless steels to examine the phase relation ship with tensile strength.

The results showed that with increasing the aging temperature from $400 \mathrm{c}^{\circ}$ to $800 \mathrm{c}^{\circ}$ the tensile strength of duplex stainless steels increased and reached its maximum value at $600 \mathrm{c}^{\circ}$ for $72 \mathrm{hrs}$. At $1000 \mathrm{c}^{\circ}$ the tensile strength decreased with increasing the aging time. For both types of duplex stainless steels these results attributed to metallurgical aspects like carbide precipitation, sigma phase, change in grain size, etc.

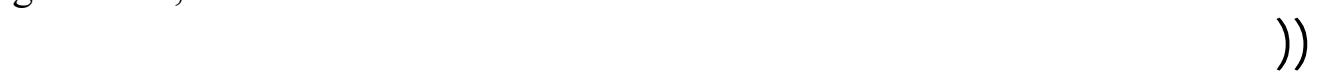

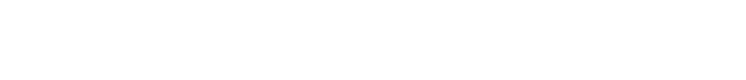

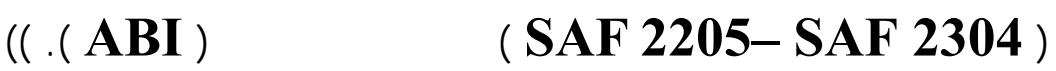 \\ $f$ tũu Đŭt Đự cã

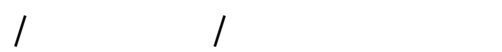

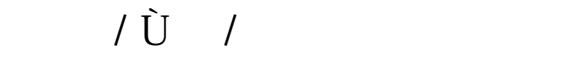

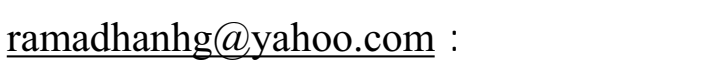

\section{rÜ+ ŤKE}

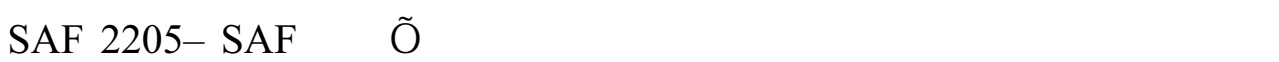

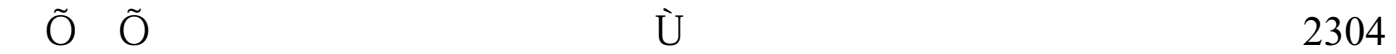

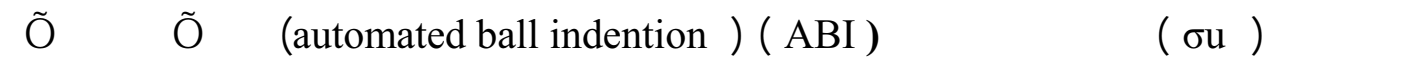

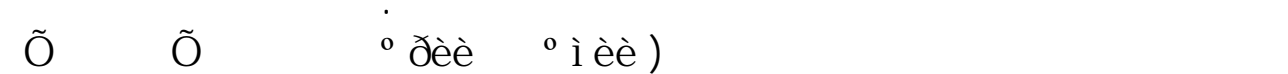
. عゴ

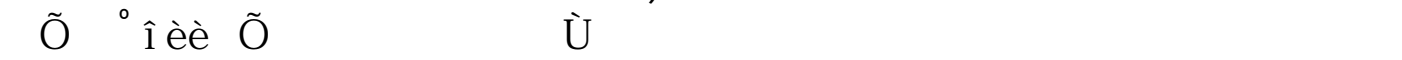

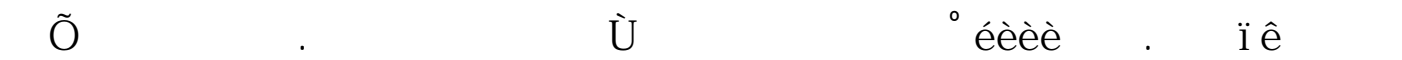

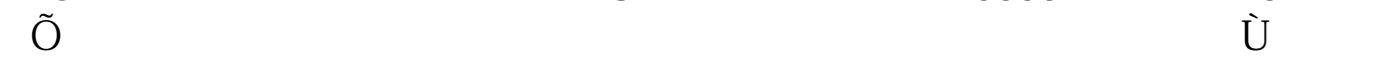

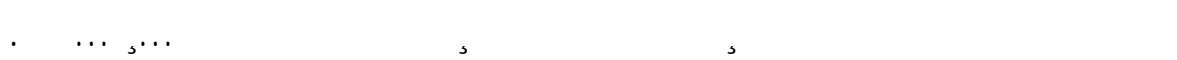




\section{Introduction}

Duplex stainless steels are iron (Fe) chromium (Cr), nickel (Ni) alloys having an austenitic and ferritic microstructure provide combinations of properties not readily attainable by conventional single phase ferritic or austenitic stainless steels. Compared to ferritic stainless steels, they can offer improved formability, weldability, and toughness; compared to austenitic stainless steels, higher strength better corrosion resistance and improved resistance to stress corrosion cracking [1]. Because of these properties duplex stainless steels are very attractive as a structural materials in chemical plant, oil and gas production and transportation, offshore drilling and pipeline applications where both high mechanical strength and excellent resistance to localized corrosion are required [2,3].

During heat treatment of duplex stainless steels some transformations involving the precipitation of sigma ( $\sigma)$, chi $(X),(\mathrm{R})$ intermetalic phases, $(\alpha)$ body centered cubic ( B.C.C ) ferrite, various carbides, and chromium nitrides, in addition to change in ferrite / austenite content and alloy recrystallization can take place[4-7]. These transformations induce marked changes in mechanical properties of these alloys. The object of this work was to study the effect of various aging time and temperature on tensile strength of duplex stainless steel alloys SAF2205 and SAF 2304

\section{Automated ball-indentation}

\section{Experimental Procedure}

(ABI) is relatively simple, rapid and non-destructive technique, requires small amount of material with very little specimen preparation, and can be adopted for in-situ testing on real structures. One of the advantages of (ABI) technique is that it is non-destructive, since no material is removed from the specimen. A smooth shallo spherical indentation, less than $0.3 \mathrm{~mm}$ deep is left at the end of the test. This spherical impression is harmless to tested structure because it has no sharp edges, and so it does not introduce any stress concentration sites. Because of the small area over which the test is carried out it is possible to determine point to point variations in mechanical properties. ABI technique is a state - of the art mechanical test that measures directly the local deformation (stress-strain) behavior of the material [8].

\section{Materials and test method}

The chemical composition of commercial duplex stainless steels SAF 2205 and SAF 2304 are given in table (1) at standard and tested condition. Fig (1) showed the microstructure of both types of duplex stainless steel alloys at as received condition. The duplex stainless steel specimens for tensile and metallographic studies were prepared by cutting (shearing process) from a sheet of $50 \times 25 \times 0.4 \mathrm{~cm}$ to required dimension $1 \mathrm{~cm} \times 2 \mathrm{~cm}$. The $2 \mathrm{~cm}$ had been parallel to rolling direction with refinishing the sheared edges. To investigate the effect of heat treatment on tensile strength of duplex stainless steel alloys five heat treatment were carried out in this study, four of them $400 \mathrm{c}^{\circ}, 500 \mathrm{c}^{\circ}, 600^{\circ}$, and $800 c^{\circ}$ were selected and for each of these temperature five different times 0.5 
$\mathrm{hr}, 10 \mathrm{hr}, 24 \mathrm{hr}$, and $72 \mathrm{hr}$, were selected, but for the fifth temperature $\left(1000 \mathrm{c}^{\circ}\right)$ three different times were selected which are $4 \mathrm{~min} ., 15 \mathrm{~min}$

Table (1): The standard and tested chemical compositions of duplex stainless steels.

\begin{tabular}{|c|c|c|c|c|c|c|c|c|c|c|c|}
\hline $\begin{array}{c}\text { Chemical } \\
\text { Composition } \\
\%\end{array}$ & $\mathrm{Cr}$ & $\mathrm{Ni}$ & $\mathrm{Mo}$ & $\mathrm{Mn}$ & $\mathrm{C}$ & $\mathrm{Si}$ & $\mathrm{P}$ & $\mathrm{N}$ & $\mathrm{V}$ & $\mathrm{Cu}$ & $\mathrm{Fe}$ \\
\hline $\begin{array}{c}\text { SAF 2205 } \\
\text { tested }\end{array}$ & 20.8 & 5.7 & 2.5 & 1.5 & 0.02 & 0.94 & 0.13 & 0.13 & 0.13 & 0.6 & Ball. \\
\hline $\begin{array}{c}\text { SAF 2205 } \\
\text { standard }\end{array}$ & 22 & 4.9 & 3 & -- & 0.03 & -- & - & $\begin{array}{c}0.08- \\
0.02\end{array}$ & -- & - & Ball. \\
\hline $\begin{array}{c}\text { SAF 2304 } \\
\text { tested }\end{array}$ & $>20.96$ & 5.3 & 0.13 & 0.86 & 0.05 & 0.89 & 0.04 & 0.11 & 0.08 & 0.3 & Ball. \\
\hline $\begin{array}{c}\text { SAF 2304 } \\
\text { standard }\end{array}$ & 23 & 4 & -- & -- & 0.03 & -- & -- & $\begin{array}{c}0.05- \\
0.2\end{array}$ & -- & -- & Ball. \\
\hline
\end{tabular}

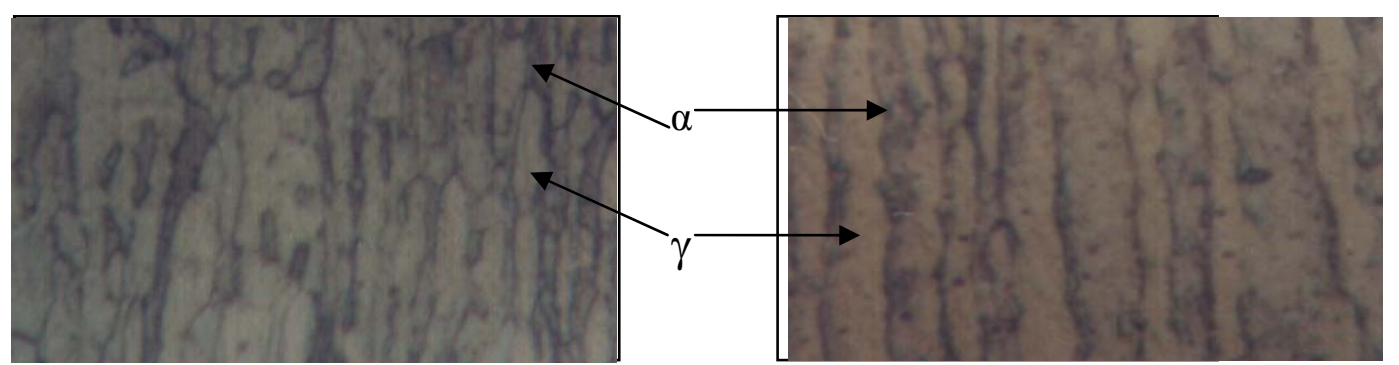

a

Fig (1) Microstructure of duplex stainless steel in as received conditions a.SAF2205, b.SAF2304 (X 1500)

where. $\alpha$ is ferrite and $\gamma$ is austenite

and 30min to coincide with the case as its take place during welding process . For tensile test and after the heat treatment the specimens were mechanically finished with the aid of 120 and 400 grid abrasive paper subsequently with using the water to avoid overheating. The specimens degreased using acetone then dried by hot air. Tensile tests were performed using (ABI) device. Three test cycles are selected of each heat treated specimens and average values have been calculated. For metallographic examination the specimens were mechanically finished with the aid of 120,220,320,600, and 1000 grid abrasive paper subsequently with using the water to avoid over heating, polishing has been done using diamond slurry. The specimens etched chemically according to ASTM standards in ferric cyanide solution. The microstructures were examined in an optical microscope. The 
austenite has a bright contrast, ferrite yellow, sigma phase, light blue and carbide containing chromium appears, as a darker phase [9].

\section{Aging at $400 \mathrm{C}^{\circ}$}

\section{Results and Discussion}

Table (2) showed the tensile strength of average values of three tests for duplex stainless steels SAF2205 and SAF2304. The results showed that in general, for both alloys with increasing the aging time the tensile strength increases. This increase is more noticeable in SAF 2304 compared with SAF 2205

Table (2) and Fig (2) showed that the tensile strength in SAF 2304 Aged at $400 c^{\circ}$ is higher than that in SAF 2205 for the same condition. This can be attribute to higher Mo,Si, and N content in SAF 2205 compared with SAF 2304 as shown in table (1). Terry and James [10] showed that the Mo acts to stabilize ferrite and austenite phases in the duplex stainless steel and retard their transformation to other phases. Tomiki Usuki [11] et al showed that with increasing Si content the susceptibility of stainless steels to sensitization retarded. Betrabet [12] showed that increasing in $\mathrm{N}$ content promote the formation of austenite phase and avoid precipitation of chromium carbide. Fig (3) showed the Microstructures for SAF 2205 and SAF 2304 heat treated at $400 \mathrm{c}^{\circ}$ for $72 \mathrm{hr}$.This Fig. demonstrate the amount of chromium carbide in SAF 2304 is higher than that for SAF2205.
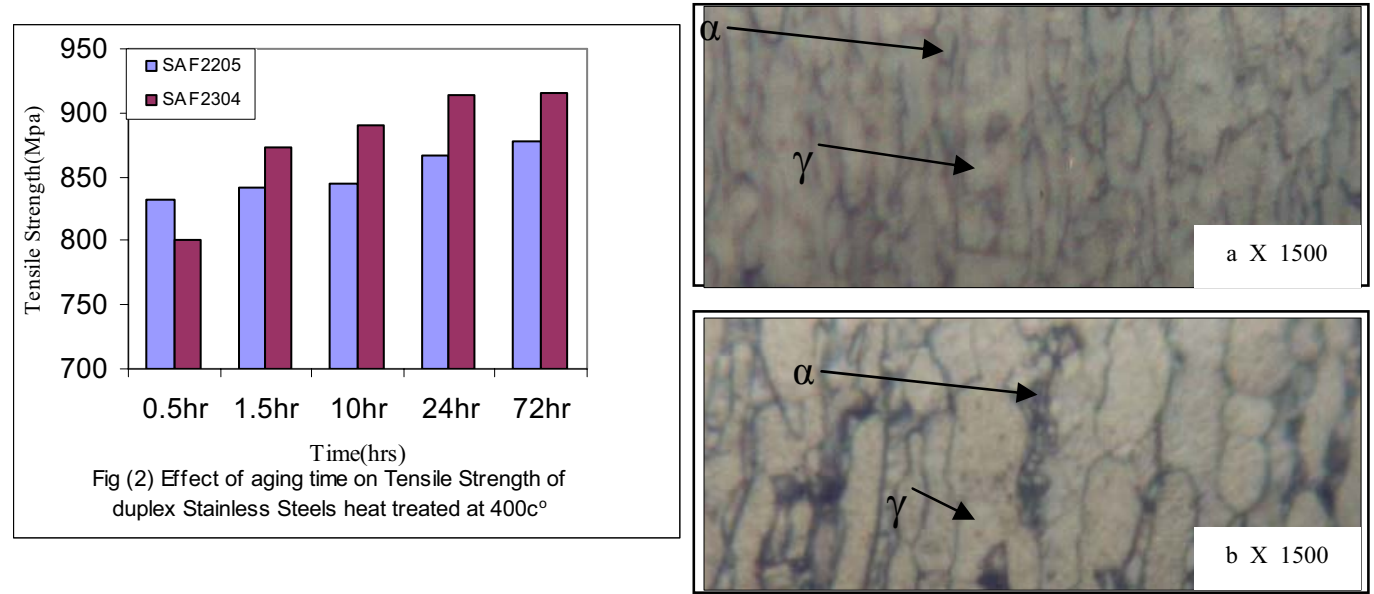

Fig (3) Microstructure of heat treated duplex Stainless Steel at $400 c^{\circ}$ for $72 \mathrm{hrs}$

a.SAF2205, b.SAF2304 


\section{Aging at $500 C^{\circ}$}

Table (2) and Fig (4) showed that with increasing the aging temperature from $400 \mathrm{C}^{\circ}$ to $500 \mathrm{C}^{\mathrm{o}}$ the tensile strength increases for the same aging times in both alloys. The tensile strength increases drastically of specimens aged for long time (72 hours) and this attributed to chromium carbides, carbonitride and decomposition of ferrite phase. N. Sridhar et al [13] showed that when ferrallum duplex stainless steel $(26 \% \mathrm{Cr}, 3 \% \mathrm{Mo}, 5.5 \% \mathrm{Ni})$ aged at $500 \mathrm{C}^{\circ}$ the ferrite phase revealed darkness due to precipitation of alpha prime $(\mathrm{Cr}$-rich bcc phase ) and carbonitrides . Ravindaranath and Malhotra [14] also showed that when the duplex stainless steel UNS (S32550) $(25 \% \mathrm{Cr}, 5 \% \mathrm{Ni}-3 \% \mathrm{Mo})$ aged at $500 \mathrm{C}^{\mathrm{o}}$ the ferrite phase decomposed to Fe-rich. and $\mathrm{Cr}$-rich phase. Fig. (5) Showed microstructure of SAF2205 and SAF2304 aged at $500 \mathrm{C}^{\mathrm{o}}$ for 72 hours: The figure illustrate that the ferrite phase revealed darkness which is believed to be alpha prime also coarsens of ferrite island can be observed, These microstructures changes contribute to increase the tensile strength .

Table (2) Tensile Strength of Aged Duplex Stainless Steels SAF2205 and SAF2304

\begin{tabular}{|c|c|c|c|}
\hline Temp. C & Time & $\begin{array}{c}\text { Tensile Strength } \\
\text { (Mpa) } \\
\text { SAF 2205 }\end{array}$ & $\begin{array}{c}\text { Tensile Strength (Mpa) } \\
\text { SAF 2304 }\end{array}$ \\
\hline as received & & 746 & 782 \\
\hline 400 & $0.5 \mathrm{hr}$ & 832 & 801 \\
\hline 400 & $1.5 \mathrm{hrs}$ & 842 & 873 \\
\hline 400 & $10 \mathrm{hrs}$ & 844 & 891 \\
\hline 400 & $24 \mathrm{hrs}$ & 866 & 914 \\
\hline 400 & $72 \mathrm{hrs}$ & 878 & 915 \\
\hline 500 & $0.5 \mathrm{hr}$ & 880 & 845 \\
\hline 500 & $1.5 \mathrm{hrs}$ & 882 & 880 \\
\hline 500 & $10 \mathrm{hrs}$ & 909 & 940 \\
\hline 500 & $24 \mathrm{hrs}$ & 911 & 962 \\
\hline 500 & $72 \mathrm{hrs}$ & 974 & 1006 \\
\hline 600 & $0.5 \mathrm{hr}$ & 840 & 851 \\
\hline 600 & $1.5 \mathrm{hrs}$ & 864 & 854 \\
\hline 600 & $10 \mathrm{hrs}$ & 1035 & 1128 \\
\hline 600 & $24 \mathrm{hrs}$ & 1070 & 1160 \\
\hline 600 & $72 \mathrm{hrs}$ & 1108 & 1181 \\
\hline 800 & $0.5 \mathrm{hr}$ & 875 & 895 \\
\hline 800 & $1.5 \mathrm{hrs}$ & 1062 & 1065 \\
\hline 800 & $10 \mathrm{hrs}$ & 1071 & 1129 \\
\hline 800 & $24 \mathrm{hrs}$ & 1092 & 1139 \\
\hline 800 & $72 \mathrm{hrs}$ & 1104 & 1157 \\
\hline 1000 & $4 \mathrm{~min}$ & 910 & 881 \\
\hline 1000 & $15 \mathrm{~min}$ & 868 & 859 \\
\hline 1000 & $30 \mathrm{~min}$ & 866 & 854 \\
\hline & & & \\
\hline
\end{tabular}



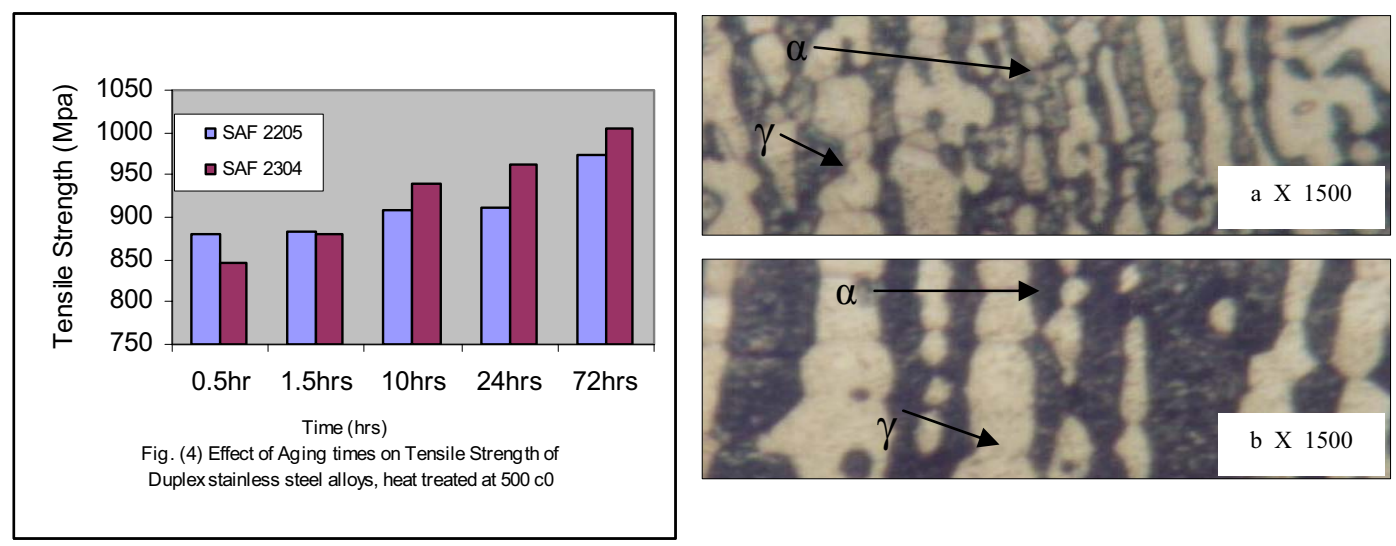

Fig (5) Microstructure of heat treated duplex Stainless Steel at $500 \mathrm{c}^{\circ}$ for $72 \mathrm{hrs}$

a.SAF2205 , b.SAF2304

\section{Aging at $600 \mathrm{C}^{\circ}$}

Table (2) and Fig (6) showed that with increasing the aging temperature to $600 \mathrm{C}^{\mathrm{o}}$, the tensile strength of duplex stainless steel alloys increased compared with $500 \mathrm{C}^{\circ}$ and $400 \mathrm{C}^{\circ}$.

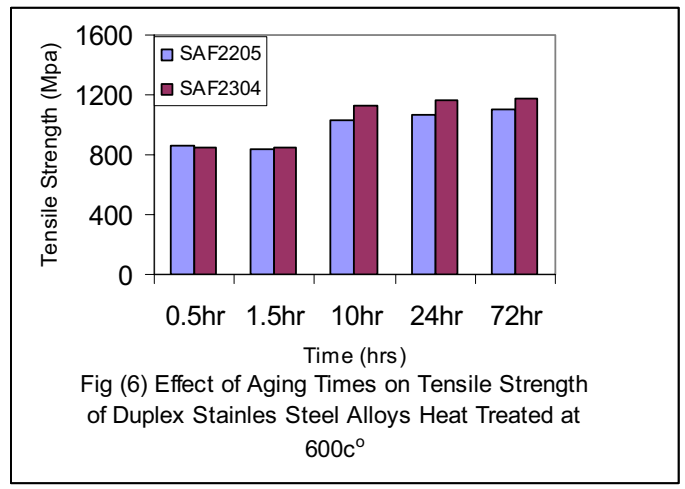

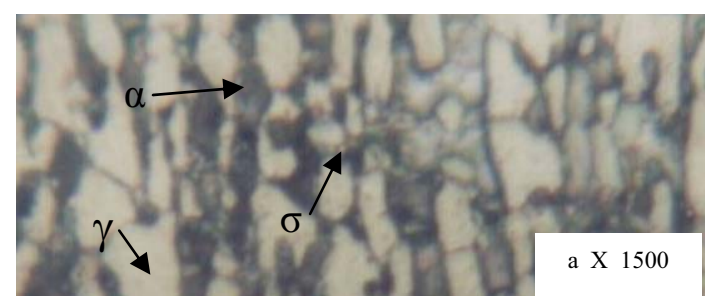

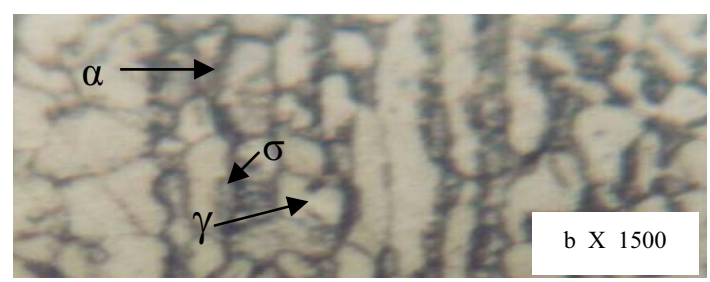

Fig (7) Microstructure of heat treated duplex Stainless Steel at $600 \mathrm{c}^{\circ}$ for $74 \mathrm{hrs}$

a.SAF2205 , b.SAf2304

Table (2) and Fig (6) showed that the duplex stainless steels exhibit maximum tensile strength when heat treated at $600 \mathrm{C}^{\circ}$ for 72 hours among all of the aging temperature and times selected in this study, which reaches $1108 \mathrm{Mpa}$ 
and $1181 \mathrm{Mpa}$ respectively. Higher and lower than this temperature the tensile strength decreases. These results refer in addition to precipitation of chromium carbide, sigma phase, to partition of ferrite and austenite islands Precipitation of Sigma $(\sigma)$ phase which has different crystal structure (Tetragonal Unit Cell) and lattice parameter compared with ferrite phase, and this produces dislocations and leads to increase tensile strength [15]. Fig (7) showed these metallurgical aspects in both type of duplex stainless steel SAF 2205 and SAF 2305.

\section{Aging at 800C}

Table (2) and Fig (8) showed with increasing the aging time at $800 \mathrm{C}^{\circ}$ the tensile strength of duplex stainless steels increased. This increase in tensile strength with increasing aging time was not as high as observed in specimens aged at $500 \mathrm{C}^{\circ}$.

Fig (9) showed microstructure of SAF 2205 and SAF 2204 aged for 72 hours. This figure showed the redistribution of ferrite phases inside austenite phases with brake down of ferrite phase into more likely islands.

Angelini et al [16] also found that when duplex stainless steel type SAF 2205 Aged at $800 \mathrm{C}^{0}$ caused the precipitation of chromium nitrides inside the austenite and the dimension of austenite elemental cell decreased significantly.
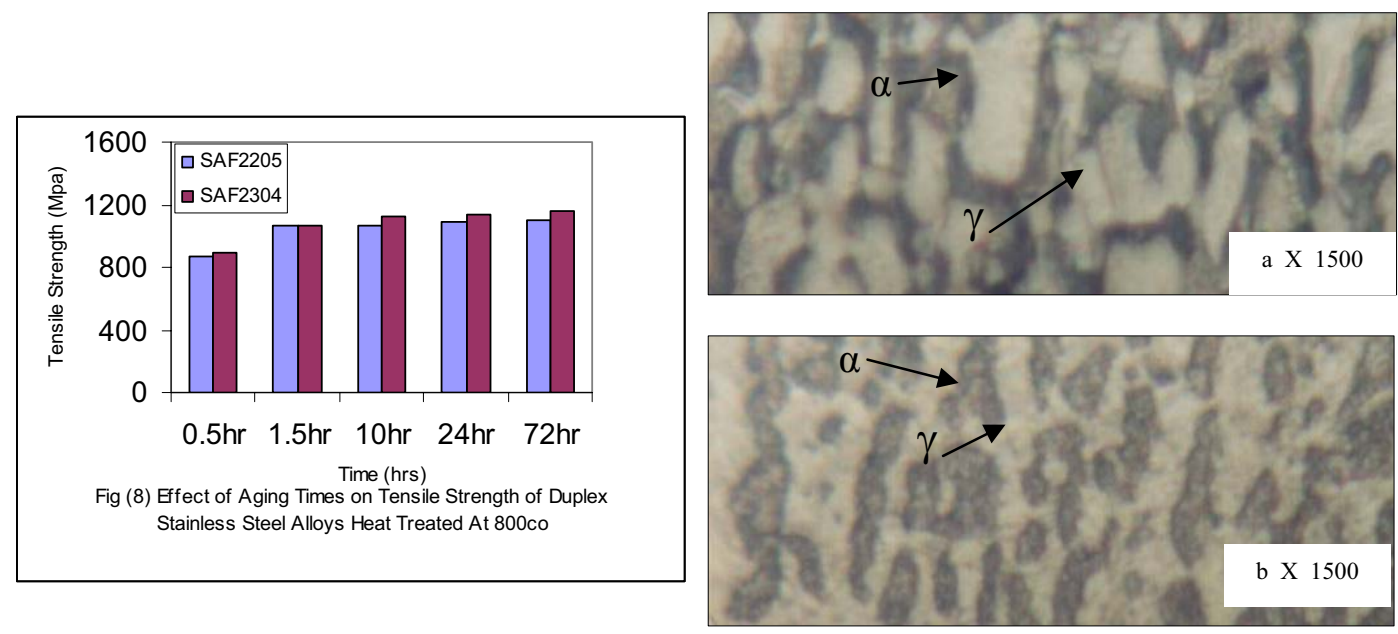

Fig (9) Microstructure of heat treated duplex Stainless Steel at $800 \mathrm{c}^{\circ}$ for $72 \mathrm{hrs}$

a.SAF2205 , b.SAF2304

The lower tensile strength of specimens aged at $800 \mathrm{C}^{\circ}$ compared with specimens aged at $600 \mathrm{C}^{\circ}$ is related to that the diffusion rate of chromium atoms towards the depleted zone which is faster due to higher temperature. This should have resulted in faster replenishment of chromium depleted zone and the possibility of formation of brittle phases will be reduced. [8] 
Increasing the tensile strength with increasing the aging time for specimens aged at $800 \mathrm{C}^{\circ}$ agreed with other investigators. J.S.Kim and H.-S. kwon [17] showed with increasing the aging time at 850 the tensile strength of duplex stainless steel $25 \% \mathrm{Cr}, 7 \% \mathrm{Ni}, 3 \% \mathrm{Mo}$ increased but toughness and ductility significantly reduced due to precipitation of chromium carbide and nitrides.

\section{Aging at $1000 c^{\circ}$}

Table (2) and Fig (10) showed that the tensile strength of duplex stainless steels aged at $1000 c^{\circ}$ decreased with increasing the aging time

Fig (11) showed Microstructure of specimens aged at 30min. of duplex stainless steel SAF 2205and SAF 2304. This figure showed the coarsen of austenite phase compared with as received condition. The effect of the change in ferrite and austenite content on strength is largely attributed to the properties of the individual phases. Ferrite generally having higher strength and less ductility and toughness than austenite. [18] hence if the percentage of austenite increased the tensile strength decreases

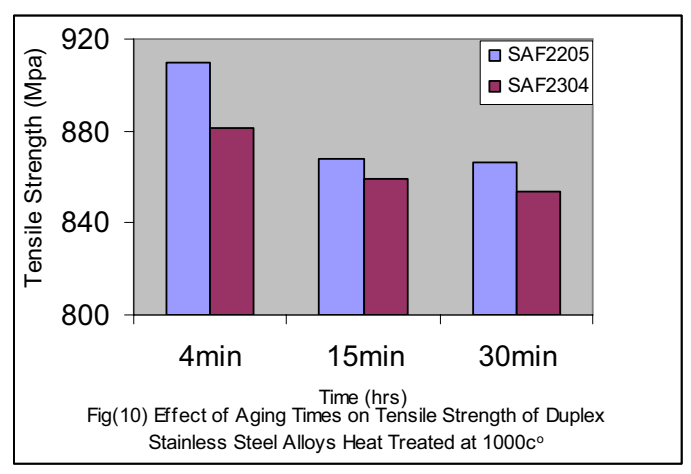
Stainless Steel Alloys Heat Treated at $1000 c^{\circ}$

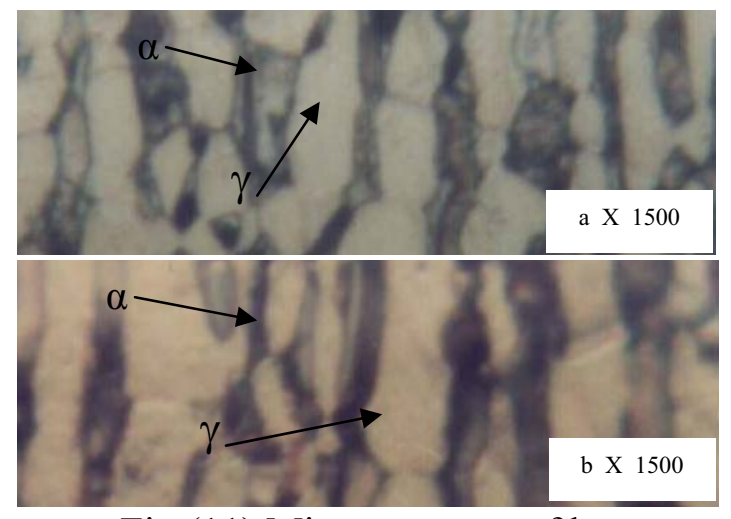

Fig (11) Microstructure of heat treated duplex Stainless Steel at 1000 co for $30 \mathrm{~min}$ a.SAF2205 , b.SAf2304

\section{Conclusion}

1. With in creasing the aging temperature from $400 c^{\circ}$ to $800 c^{\circ}$ the tensile strength increased in all aging time.

2. At $500 c^{\circ}$ tensile strength increased drastically when aging time is 72 hours.

3. The tensile strength reached its maximum values at $600 c^{\circ}$ for 72 hours.

4. At $1000 c^{\circ}$ the tensile strength decreases with increasing the aging time.

5. At $600 c^{\circ}$ and $800 c^{\circ}$ the tensile strength of SAF 2304 is higher than the SAF 2205 , and vise versa at $1000 c^{\circ}$. 


\section{References}

1. J.J.Ecknnrod and Kenneth E. Pinnow (Effect of chemical composition and thermal history on the properties of alloy 2205 duplex stainless steel proc. conf New development in stainless steel technique) Detroit, paper No. 8410-029. PP. 77, (1985)

2. J. Charles (Super Duplex Stainless steel: structure and properties) Proc conf. steel 91, October 1991 (Les Ulis France: Les edition de physique, 1991), p.3.

3. R.D. Kane, Adv. Mater proc. 144 (1991): P.16.

4. B. Josef son, J.O. Nilsson, A. Wilson, phase transformation in duplex steels and the relation between continuous cooling and Isothermal heat treatment, proc. conf duplex stainless steel 91, October (Les Ulis, France: Les edition de physique, 1991), P. 67.

5. A.J. Strutt, J.W. Larimer (structure property Relation ships of Zeron 100,) proc conf. Phase transformation 87, Cambridge, U.K. (London, U.K: Institute of Metals, 1987), P.178

6. H. Hoffmeister, Quantitative Effect of Nitrogen contents and cooling cycles on $\gamma$ Transformation, chromium nitride precipitation, and pitting corrosion After Weld Simulation of duplex stainless steel proc. conf. duplex stainless steel, 94 November 1994, paper no. 55 (London) U.K.: Institute of Metals, 1994.

7. K. Ravindranath, S.N. Malhotra, Cross. Sci. 37 (1995): P.121

8.K.L. Murty M D Mathew, Journal of Materials Science Vo. 34, (1999) P.P. 1498.

9. ASTME3 Standard Test Method For Metallographic of Metals in Annul Book of ASTM, (1978) P.P 57.

10. D.A.D. Terry, W.M. Jams and D.A. Engle heart "corrosion Resistance and Mechanical properties of a new duplex stainless steel. Proc. conf New Development in stainless steel Technique Detroit paper No. 8410 -017, (1985) PP. 89.

11. T. Usuki H. Kajimura, H. Morikaw, and H. Hangano, Corrosion Resistance of High Silicon duplex stainless steel in Nitric Acid, presented at the 114 to ISIJ Meting, August, Lecturer No. S1322, (1987) P.P 73.

12. H.S. Beterabet, K. Nishimoto, E.Wilde and W.A.T clerk, corrosion Volt. 43, No, 2, (1987) P.P. 77.

13. N. Sridhar, J. kolts and L.H. F lasche, Metal, (1985) PP.31.

14. K. Ravindranath and S.N. Malhotra, corrosion vol. 50. No.4 (1994). P.P 320.

15. T. Sourmail, Materials Science and Technology, Jan. (2001) Vol. 17 P.P. 9

16. E. Angelini, B. De Benedetti, G. Maizza F. Rosalbino, Corrosion Vol. 55, No. 6 (1999) P.P 608.

17.J.S. Kim and H.S. Kown, corrosion vol. 55, No.5 (1999). PP516.

18. Gooch T. G. weld ability of Duplex Ferritic - Austenitic Stainless

Steels, Corrosion Science Vol. 29 No. 4 Paper No. 8201-029 P.P. 585. 